\title{
Climate Change Impacts on Streamflow in Taiwan Catchments Based on Statistical Downscaling Data
}

\author{
Yun-Ju Chen ${ }^{1, *}$, Jung-Lien Chu ${ }^{1}$, Ching-Pin Tung ${ }^{2}$, and Keh Chia Yeh ${ }^{3}$ \\ ${ }^{1}$ National Science and Technology Center for Disaster Reduction, New Taipei City, Taiwan, R.O.C. \\ ${ }^{2}$ Department of Bioenvironmental Systems Engineering, National Taiwan University, Taipei City, Taiwan, R.O.C. \\ ${ }^{3}$ Department of Civil Engineering, National Chiao Tung University, Hsinchu, Taiwan, R.O.C.
}

Received 31 July 2015, revised 15 March 2016, accepted 20 July 2016

\begin{abstract}
This study investigated the streamflow impacts in wet and dry spells using a statistical downscaling projection method to obtain $5 \mathrm{~km}$ girds under four Representative Concentration Pathway (RCP) scenarios. Two upstream catchments, the Dahan and Laonong Rivers were selected as the study areas. A water balance hydrological model, also known as the Generalized Watershed Loading Function model, was used to simulate the streamflow impacts. There are 126 projections from 41 general circulation models (GCMs) and 4 RCPs used in this analysis. The analytical results indicate that the streamflow impacts in different RCP scenarios are significant but vary with individual GCM's projection. The variance of 20 selected GCMs is close to that of all other GCMs. Typically, more than $60 \%$ of GCMs project that in the early $21^{\text {st }}$ century, streamflow in each RCP increases by $0-40 \%$ in wet spells and decrease by $-40 \sim 0 \%$ for the Dahan River, but the streamflow increases during both wet and dry spells for the Laonong River. In the late $21^{\text {st }}$ century, the streamflow decreases by $60 \%$ during dry spells in the Laonong River. Various predictions for the early and late $21^{\text {st }}$ century show high variance of streamflow impacts. As such, decision makers must plan for reservoir operation and flexible water deployment adaptations during future dry spells.
\end{abstract}

Key words: RCP, Statistical downscaling, Water balance model, Variance, GCM

Citation: Chen, Y. J., J. L. Chu, C. P. Tung, and K. C. Yeh, 2016: Climate change impacts on streamflow in Taiwan catchments based on statistical downscaling data. Terr. Atmos. Ocean. Sci., 27, 741-755, doi: 10.3319/TAO.2016.07.20.01

\section{INTRODUCTION}

Taiwan is located in a subtropical region with an average annual rainfall of $2500 \mathrm{~mm}$. This amount is approximately 3 times as much as the world average. However, the Taiwan rainfall distribution is uneven in the temporal and spatial dimensions. The streamflow cannot be easily retained because the rivers are short and steep. The precipitation during the wet season must be retained in distributed reservoirs for use during the dry season. Rainfall and streamflow fluctuate greatly in the wet and dry seasons in Taiwan. This makes water resource utilization and management particularly difficult.

Climate change is disrupting the global hydrological cycle in many regions. Climate change affects, and will continue to affect, the quantity and quality of water resources (Barnett et al. 2005; Bae et al. 2011; Thompson et al. 2013;

\footnotetext{
* Corresponding author

E-mail:yjchen@ncdr.nat.gov.tw
}

IPCC 2014). Climate change has different impacts on river discharge worldwide (Thodsen 2007; Sato et al. 2012; Hong et al. 2014). Previous studies that used scenarios from the Third Assessment Report (TAR) of the Intergovernmental Panel on Climate Change (IPCC) indicated that streamflow in Taiwan will decline during the dry season and increase during the wet season (Tung 2001; Yu et al. 2002; Li et al. 2009; Tung et al. 2012). Taiwan's water demand has grown under global climate change and rapid social and economic development. The variations in streamflow in wet and dry periods exacerbate water management difficulties, resulting in seasonal water shortages (Lin et al. 2010; Tsai and Huang 2011). Higher precipitation variations between wet and dry seasons have been predicted in Representative Concentration Pathway (RCP) scenarios in the Fifth Assessment Report (AR5) of the IPCC. It has been predicted that these water resource problems may increase. Hydrological impacts should therefore be estimated using RCP scenarios to anticipate future water resource problems. 
The hydrological impacts of climate change are commonly evaluated by forcing a hydrological model with climate projections derived from a general circulation model (GCM) under different emission scenarios with downscaling methods and weather generation models. Uncertainty is associated with each stage of the hydrological evaluation process for the impacts of climate change (Gosling and Arnell 2011; Thompson et al. 2014). Previous studies have suggested several principles for reducing uncertainty, including (1) using multiple climate models; (2) using multiple downscaling methods; (3) using multiple hydrological models, projection methods, and operational applications; (4) increasing intercommunication; (5) assessing impacts using different spatial scales; (6) and applying bias correction for model data (Carter 2001; Nawaz and Adeloye 2006; Prudhomme and Davies 2009; Gosling and Arnell 2011). If only a single GCM or a few GCMs are used to assess the impacts of climate change, the uncertainty becomes higher. The climate change impact result should be indicated using a range (or probability) instead of a single GCM. Most researchers consider multiple GCMs and scenarios, as well as multiple model ensembles (MME) to reduce the uncertainty (Diallo et al. 2012; Knutti and Sedláček 2013).

The spatial resolution of typical GCMs (approximately $150-300 \mathrm{~km}$ ) from the IPCC data centre is too coarse for a watershed study in Taiwan. Hence, a downscaling method is necessary for climate change impact assessment. Generally, the technical and computational demand of the regional circulation model is higher than statistical downscaling. Using several scenarios and GCMs with statistical downscaling is suggested to quickly obtain high-resolution projection data. A bias correction statistical downscaling method was used in this study. Most variables that GCMs project (e.g., precipitation and temperature) are in monthly scale. Thus, a weather generator is needed to produce daily data for a long time series to apply hydrological impact assessments (Mavromatis and Hansen 2001). A statistical downscaling method and weather generator technique are used to provide rainfall and temperature inputs for hydrological models to assess streamflow impacts under different GCMs and scenarios.

There are many types of hydrological models, including global models, lumped or semi-distributed models, and physical-based models. To reduce the uncertainty of the hydrological evaluation process, a physical hydrological model with few parameters is suggested. The Generalized Watershed Loading Function (GWLF), a lumped conceptual water balance model, is a physical process model (Evans et al. 2002). Moreover, the GWLF has been used worldwide for assessing changes in streamflow (Chang 2003; Wu et al. 2007; Tung et al. 2012; Chiang et al. 2013) and for assessing climate change impacts ( $\mathrm{Li}$ et al. 2009; Schneiderman et al. 2010).

The study framework is shown in Fig. 1. This study applied the climate projection data (precipitation and temperature) of 41 GCMs under four RCPs (RCP2.6, RCP4.5, RCP6.0, and RCP8.5) from the AR5 of the IPCC data center. The climate projections were analyzed for the early $21^{\text {st }}$ century (2016 - 2035) and the late $21^{\text {st }}$ century $(2081-2100)$ with respect to the late $20^{\text {th }}$ century $(1986-2005)$. After statistical downscaling, $5 \mathrm{~km}$ grid projected climate data were produced. A weather generator was then applied to generate daily precipitation and temperature data for GWLF model input. Finally, the GWLF was used to assess the streamflow change ratios between the late $20^{\text {th }}$ century periods and the $21^{\text {st }}$ century periods. The variances of simulated streamflow change ratios from different GCMs and scenarios were used to express the uncertainty of projections. In the later sections of this paper, the results for the two catchments are presented

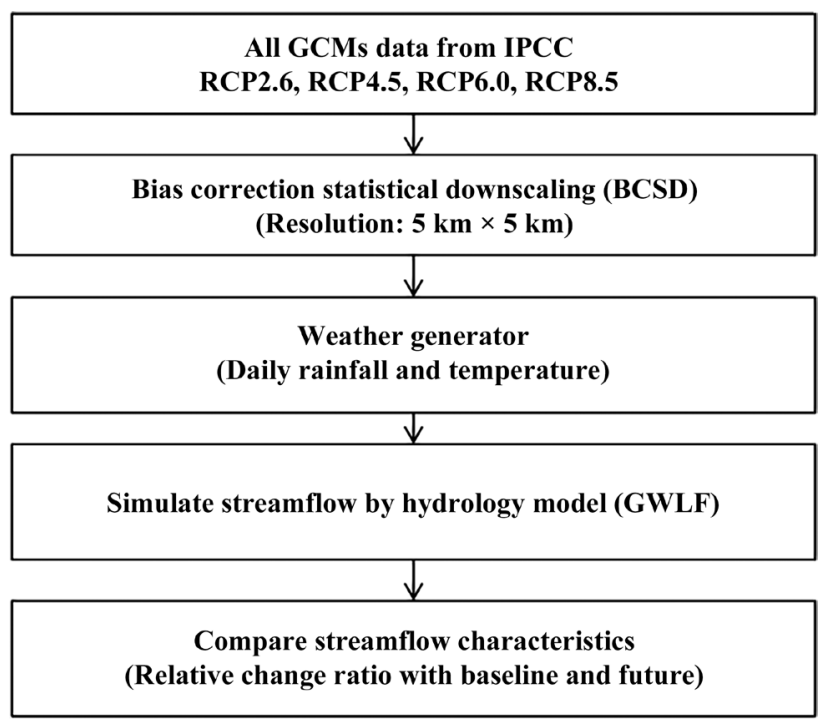

Fig. 1. Flowchart of this study. 
and discussed, and some major findings are summarized.

\section{STUDY AREA AND DATA}

This study discusses two catchments for assessing the impacts of climate change on streamflow. One catchment located in Northern Taiwan is the Dahan River, which is a subcatchment of the Danshui River. The other river, the Laonong River, is located in Southern Taiwan a subcatchment of the Gaoping River (Fig. 2). These two rivers are crucial water resources that supply drinking water to New Taipei City and Kaohsiung City, respectively.

The Dahan River with a length of $135 \mathrm{~km}$ is the major tributary of the Danshui River, the third longest river in Taiwan. The Dahan River catchment area is $1163 \mathrm{~km}^{2}$ and the streamflow is the main inflow to the Shimen Reservoir. The reservoir serves flood storage, power generation, water supply, and irrigation functions. The average annual precipitation is $2430 \mathrm{~mm}$ and $70 \%$ of this precipitation falls from May to October. The monthly average precipitation in the period from September to the following January is less than $100 \mathrm{~mm}$, whereas the monthly average precipitation in the period from May to August is greater than $290 \mathrm{~mm}$. The mean annual temperature in the catchment is approximately $15.7^{\circ} \mathrm{C}$. The average annual discharge is $30.22 \mathrm{cms}$ in the upstream watershed of Dahan River (Water Resources Agency).

The Laonong River is the largest river catchment in Taiwan with an area of $2038 \mathrm{~km}^{2}$ and a length of $133 \mathrm{~km}$. This catchment is located in a subtropical area and as such, there is a significant difference in rainfall between the wet and dry seasons. The average annual rainfall is $3344.9 \mathrm{~mm}$ and $91 \%$ of the annual rainfall occurs during the wet season (from May to October). Only 9\% of the annual rainfall occurs in the dry season (from November to April of the next year). The average annual discharge is $51.56 \mathrm{cms}$ in the upstream watershed of Laonong River (Water Resources Agency). The mean annual temperature is $24.5^{\circ} \mathrm{C}$. The annual evaporation is between 1000 and $2000 \mathrm{~mm}$.

The locations of rain gauges and flow observation stations as well as the land cover of the Dahan River and Laonong River catchments are shown in Fig. 2. The land cover map was provided by the National Land Surveying and Mapping Center (2006). The Dahan River catchment is comprised of $92.4 \%$ forest, $2.8 \%$ agricultural land, $2.2 \%$ water conservancy land, $0.6 \%$ grassland, and $2.1 \%$ land for other uses. The Laonong River catchment is comprised of $83 \%$ forest, $5.6 \%$ agricultural land, $2.34 \%$ water conservancy land, $3.1 \%$ grassland, and $5.9 \%$ land for other uses. Table 1 lists the temperature gauge stations, precipitation stations, and streamflow stations that supplied information to verify the hydrological model. There is no temperature gauge station upstream of the catchments. This study assumed that the surface temperatures decrease linearly with elevation, also known as the lapse rate. Typically, a lapse rate of 6.0 or $6.5^{\circ} \mathrm{C} \mathrm{km}^{-1}$ has been used to estimate surface temperature in various previous studies (e.g., Maurer et al. 2002; Roe and O'Neal 2009). A lapse rate of $6.5^{\circ} \mathrm{C} \mathrm{km}^{-1}$ was applied to the two temperature gauge stations (Taipei and Kaohsiung) to estimate the upstream temperatures in the two catchments.

\section{METHODS}

\subsection{Statistical Downscaling Method}

Because GCMs have difficulty in simulating regional climates, GCM outputs are downscaled to obtain finer spatial resolutions for local impact studies. Downscaling

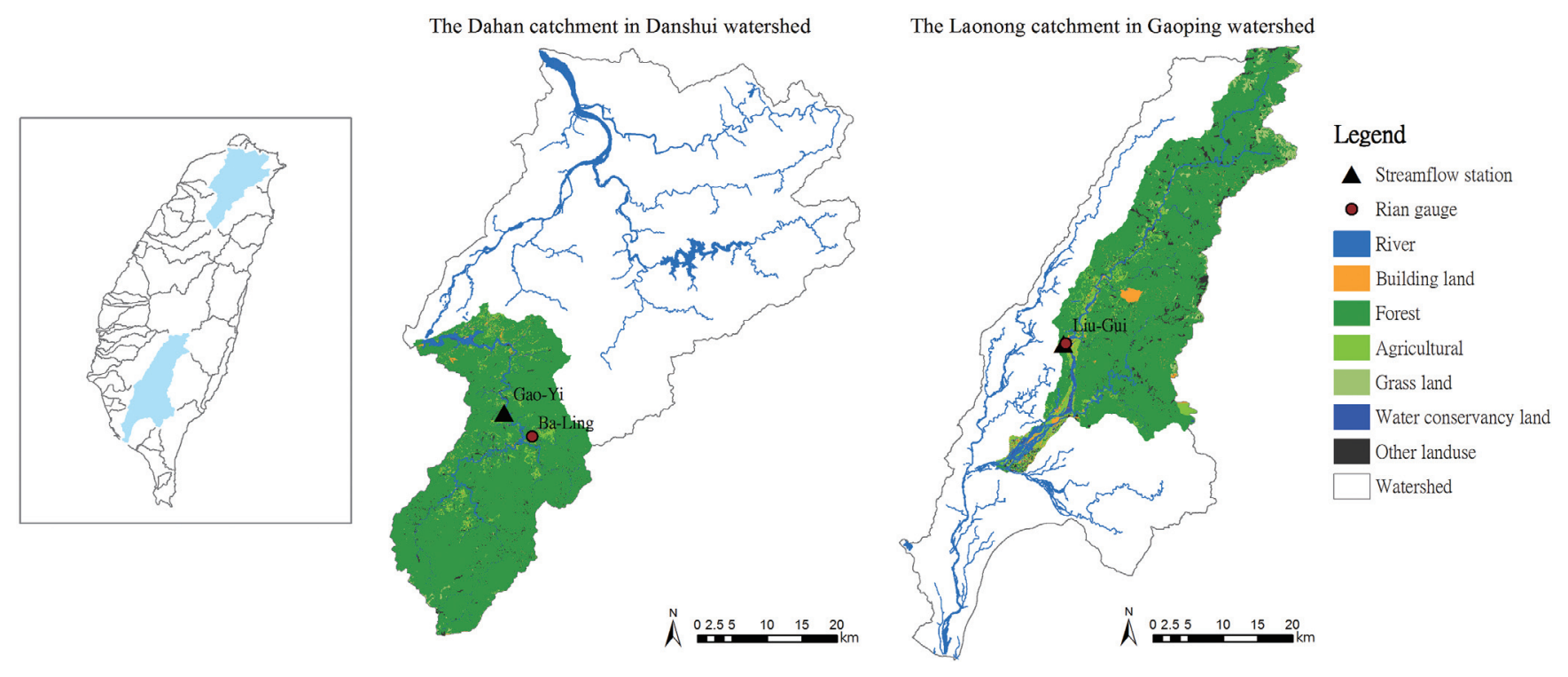

Fig. 2. Dahan River and Laonong River catchments locations and landuse. 
Table 1. Information of observation stations.

\begin{tabular}{c|ccc}
\hline Catchment & Kinds of observation & Station name & Record length \\
\hline \multirow{3}{*}{ Dahan River } & Temperature & Taipei & $1965-2013$ \\
& Precipitation & Ba-Ling & $1937-2013$ \\
& Streamflow & Gao-Yi & $1957-2013$ \\
\hline \multirow{3}{*}{ Laonong River } & Temperature & Kao-Hsiung & $1950-2013$ \\
& Precipitation & Liu-Gui & $1982-2013$ \\
& Streamflow & Liu-Gui & $1982-2009$ \\
\hline
\end{tabular}

methods can be categorized into two types. The first is the dynamic downscaling method, which involves a regional climate model driven by GCM outputs that can provide highresolution simulations, which in turn can simulate extreme events. The second type is statistical downscaling, which aims to discover statistical relationships between large-scale predictors (e.g., pressure fields) and local climate variables (e.g., precipitation and temperature). These relationships are applied to global climate model experiment outputs to simulate future local climate characteristics (Von Storch and Zwiers 1984). These methods are widely applied to climate change studies because of their low computational requirements. The statistical downscaling process can be applied to several GCMs and several different emission scenarios relatively quickly and inexpensively (Benestad 2002).

Most statistical downscaling methods can be divided into three types, weather typing (Hughes and Guttorp 1994), weather generator (Richardson 1981; Semenov and Brooks 1999), and regression methods (Von Storch and Zwiers 1984; Wood et al. 2002; Chu et al. 2008). The bias correction spatial disaggregation method (BCSD) (Hay and Clark 2003; Wood et al. 2004; Fowler et al. 2007; Maurer 2007; Maurer and Hidalgo 2008; Maraun et al. 2010) is applied in this study to refine temperature and precipitation data resolutions. BCSD has the advantage of preserving the simulated regional climate variability in GCMs for statistical downscaling. Details for applying BCSD to Taiwan are provided in Chen et al. (2014).

GCMs encounter a challenge when simulating regional climates using fine meshes. Although GCMs can capture climate signals from large-scale circulation, systematic biases can still be found in the GCM outputs. Bias correction for GCMs is required to make the simulation more reasonable. In general, the observed monthly high-resolution rainfall is interpolated to the scale of a given GCM in bias correction. The observed monthly high-resolution rainfall and climate model simulation outputs were first converted and upscale interpolated into $2^{\circ} \times 2^{\circ}$ resolution in this study to compare models, as shown in Fig. 3.

High-resolution $\left(0.25^{\circ} \times 0.25^{\circ}\right)$ observed precipitation data derived using Asia Precipitation Highly-Resolved Observational Data (APHRODITE) (Yatagai et al. 2012) were used for the 1951 - 2007 period. The APHRODITE domain for downscaling was set as $60-150^{\circ} \mathrm{E}$ and $15^{\circ} \mathrm{S}-55^{\circ} \mathrm{N}$. The observed global temperature dataset provided by the Climate Research Unit, University of East Angelia (Mitchell and Jones 2005) was also used. The spatial resolution was $0.5^{\circ} \times 0.5^{\circ}$, and the $1901-2002$ period was chosen for downscaling.

Second, the cumulative distribution function (CDF) for long-term observation data for each grid cell was applied to correct the CDF simulation model. The simulated monthly precipitation and temperature with a spatial resolution of $2^{\circ} \times 2^{\circ}$ were corrected using the relationship between the two CDFs. Note that the long-term trend was removed in advance for the temperature field during CDF calculation. Cross-validation was conducted in the model bias correction process. The correction coefficient was then defined using the ratio between the monthly mean corrected model outputs and the observation data climatology for each $2^{\circ} \times 2^{\circ}$ grid point. Subsequently, correction coefficient fields with high spatial resolution were generated using the inverse distance weighting method, which is a type of spatial interpolation method. Finally, the downscaling results were obtained by multiplying the observation data climatology for a given month by the high-resolution correction coefficient field. The downscaling procedure was repeated twice in this study, gradually from $0.25^{\circ} \times 0.25^{\circ}$ (first stage) to $0.05^{\circ} \times 0.05^{\circ}$ (second stage) grid points to obtain a finer spatial variation map of the Taiwan area.

The BCSD was used to produce $5 \mathrm{~km}$ resolution climatic projections (precipitation and temperature) in two projection periods for all RCP scenarios and GCMs, which are listed in Table 2. There are 20 GCMs containing four $\mathrm{RCP}$ scenarios among all projections.

\subsection{Weather Generation}

Most hydrology simulation models require daily weather data as the input data, so the monthly data of the GCMs projection must be refined to daily data. Weather generators are applied extensively to produce daily weather data in climate change scenarios to evaluate agricultural and hydrological risks (Mavromatis and Hansen 2001). Weather 
generators use meteorological data statistical characteristics similar to those of weather station observations (Richardson and Wright 1984; Tung and Haith 1995; Semenov and Brooks 1999; Wilks and Wilby 1999) to simulate time-series daily weather data. Markov chains are used to evaluate the precipitation process (to determine whether a day is rainy or dry), in which the total rainy day precipitation is determined by randomly choosing a value generated from a suitable statistical distribution, such as an exponential, gamma, or Weibull distribution. Large amounts of series data are produced using random seeds, and the data have the same statistical characteristics as the source data do. This enables validating the statistical model. This study adopted the temperature and precipitation model proposed by Tung and Haith (1995), which uses daily weather data as input, and calculated daily temperature and precipitation based on monthly precipitation projections at $5 \mathrm{~km} \times 5 \mathrm{~km}$ resolution after statistical downscaling.

Regarding climate change applications, this study mainly used the temperature and precipitation outputs from GCMs under current and future climate conditions. The monthly average temperature and precipitation were cor- rected on the basis of projections to obtain the default conditions for future climate scenarios. Temperature corrections were based on temperature differences. Precipitation corrections were based on precipitation ratios. The corrected future monthly average temperature was the historical value plus the temperature difference. The corrected monthly average precipitation was the historical precipitation multiplied by the precipitation ratio.

\subsection{Hydrological Model}

Many studies combined GCMs and hydrological models to assess water resource, streamflow, or ecosystem effects on catchment scales ( $\mathrm{Li}$ et al. 2009; Tung et al. 2012; Chiang et al. 2013; Niraula et al. 2013). The GWLF, a physic-based model, was chosen as the hydrological model for assessing streamflow impacts in this study. The GWLF can be applied to a variety of catchments situated in regions with very different climates. The GWLF parameters are based on the physical properties of the catchment; therefore, the uncertainty of this model is less than that of other complex models. The parameters are adjusted according to land use,

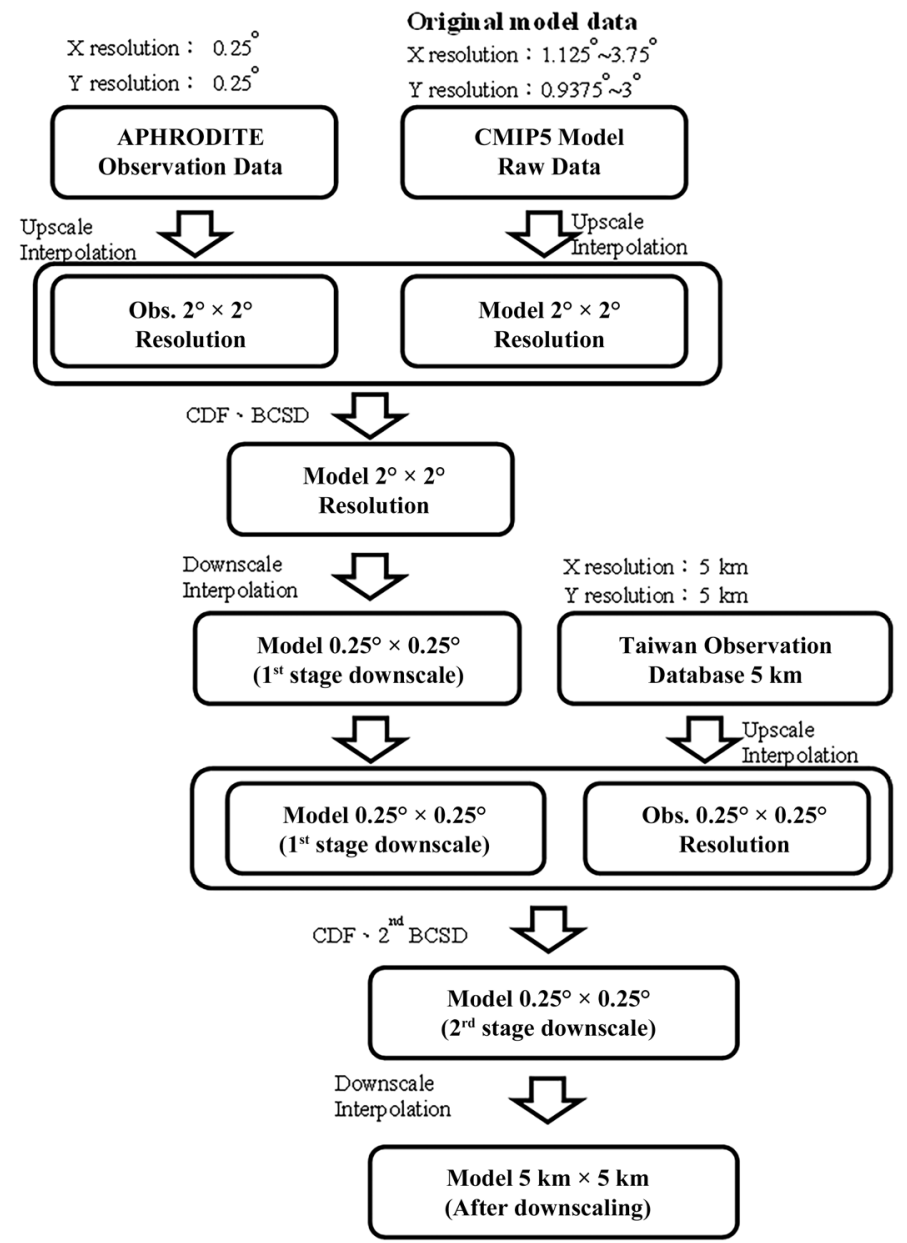

Fig. 3. The flowchart for statistical downscaling (Chen et al. 2014). 
Table 2. List of Model Name and RCP Scenarios.

\begin{tabular}{|c|c|c|c|c|c|}
\hline \multirow{2}{*}{ No. } & \multirow{2}{*}{ Name of GCMs } & \multicolumn{4}{|c|}{ Scenario } \\
\hline & & RCP2.6 & RCP4.5 & RCP6.0 & RCP8.5 \\
\hline 1 & bcc-csm1-1-m* & $\circ$ & $\circ$ & $\circ$ & $\circ$ \\
\hline 2 & bcc-csm $1-1 *$ & $\circ$ & $\circ$ & $\circ$ & $\circ$ \\
\hline 3 & CCSM4* & ○ & $\circ$ & $\circ$ & $\circ$ \\
\hline 4 & CESM1-CAM5* & $\circ$ & $\circ$ & $\circ$ & $\circ$ \\
\hline 5 & CSIRO-Mk3-6-0* & ० & $\circ$ & $\circ$ & $\circ$ \\
\hline 6 & FIO-ESM* & ○ & $\circ$ & $\circ$ & $\circ$ \\
\hline 7 & GFDL-CM3* & $\circ$ & $\circ$ & $\circ$ & $\circ$ \\
\hline 8 & GFDL-ESM2G* & $\circ$ & $\circ$ & $\circ$ & $\circ$ \\
\hline 9 & GISS-E2-H* & $\circ$ & $\circ$ & $\circ$ & $\circ$ \\
\hline 10 & GISS-E2-R* & $\circ$ & $\circ$ & $\circ$ & $\circ$ \\
\hline 11 & HadGEM2-AO* & $\circ$ & $\circ$ & $\circ$ & $\circ$ \\
\hline 12 & HadGEM2-ES* & $\circ$ & $\circ$ & $\circ$ & $\circ$ \\
\hline 13 & IPSL-CM5A-LR* & $\circ$ & $\circ$ & $\circ$ & $\circ$ \\
\hline 14 & IPSL-CM5A-MR* & ० & $\circ$ & $\circ$ & $\circ$ \\
\hline 15 & MIROC-ESM-CHEM* & ० & $\circ$ & $\circ$ & $\circ$ \\
\hline 16 & MIROC-ESM* & $\circ$ & $\circ$ & $\circ$ & $\circ$ \\
\hline 17 & MIROC5* & $\circ$ & $\circ$ & $\circ$ & $\circ$ \\
\hline 18 & MRI-CGCM3* & $\circ$ & $\circ$ & $\circ$ & $\circ$ \\
\hline 19 & NorESM1-ME* & ० & $\circ$ & $\circ$ & $\circ$ \\
\hline 20 & NorESM1-M* & $\circ$ & $\circ$ & $\circ$ & $\circ$ \\
\hline 21 & GFDL-ESM2M & & $\circ$ & $\circ$ & $\circ$ \\
\hline 22 & ACCESS1-0 & & $\circ$ & & $\circ$ \\
\hline 23 & ACCESS1-3 & & $\circ$ & & $\circ$ \\
\hline 24 & BNU-ESM & $\circ$ & $\circ$ & & $\circ$ \\
\hline 25 & CanESM2 & $\circ$ & $\circ$ & & $\circ$ \\
\hline 26 & CESM1-BGC & & $\circ$ & & $\circ$ \\
\hline 27 & CESM1-CAM5-1-FV2 & & $\circ$ & & $\circ$ \\
\hline 28 & CMCC-CESM & & & & $\circ$ \\
\hline 29 & CMCC-CMS & & $\circ$ & & $\circ$ \\
\hline 30 & CMCC-CM & & $\circ$ & & $\circ$ \\
\hline 31 & CNRM-CM5 & $\circ$ & $\circ$ & & $\circ$ \\
\hline 32 & EC-EARTH & & & & $\circ$ \\
\hline 33 & FGOALS-g2 & $\circ$ & $\circ$ & & $\circ$ \\
\hline 34 & GISS-E2-H-CC & & $\circ$ & & $\circ$ \\
\hline 35 & GISS-E2-R-CC & & $\circ$ & & $\circ$ \\
\hline 36 & HadGEM2-CC & & $\circ$ & & $\circ$ \\
\hline 37 & inmem4 & & $\circ$ & & $\circ$ \\
\hline 38 & IPSL-CM5B-LR & & $\circ$ & & $\circ$ \\
\hline 39 & MPI-ESM-LR & $\circ$ & $\circ$ & & $\circ$ \\
\hline 40 & MPI-ESM-MR & ○ & $\circ$ & & $\circ$ \\
\hline 41 & MRI-ESM1 & & & & $\circ$ \\
\hline
\end{tabular}

Note: '*' means the GCMs projected under four scenarios. soil texture, and future climate change. The GWLF uses land use data, soil data, and daily weather data to calculate the water balance. The GWLF allows multiple land uses within an area, but the model considers other parameters for each area to be uniform (Niraula et al. 2013). The monthly streamflow simulation is based on the daily water balance aggregated to monthly values (Haith and Shoenaker 1987; Haith et al. 1992).

The GWLF model is a combined distributed/lumped parameter, continuous watershed model (Evans et al. 2002) that simulates the hydrological cycle, surface runoff, and groundwater discharge. The surface runoff is estimated using the Soil Conservation Service curve number method (SCS-CN). The groundwater discharge is estimated by assuming a shallow saturated zone as a linear reservoir. The streamflow is simulated based on the following water balance equation:

$S F_{t}=S R_{t}+G W_{t}$

$S F_{t}=\frac{\left(R_{t}-0.2 W_{t}\right)^{2}}{\left(R_{t}+0.8 W_{t}\right)}+\left(r \times S_{t}\right)$

where $S F_{t}(\mathrm{~cm})$ is the final streamflow on day $t, S R_{t}(\mathrm{~cm})$ is the amount of surface runoff on day $t, G W_{t}(\mathrm{~cm})$ is the amount of groundwater discharge on day $t ; R_{t}(\mathrm{~cm})$ is the amount of rainfall on day $t, W_{t}=2540 / C N_{t}-25.4, C N_{t}$ is a curve number and a function of the land uses, and $S_{t}(\mathrm{~cm})$ is the storage of the shallow saturated zone. Detailed GWLF descriptions are provided in Haith and Shoenaker (1987) and Haith et al. (1992).

The projected impacts of climate change on streamflow were analysed using three steps (Chiew et al. 1995; Andréasson et al. 2004; Charlton et al. 2006). The GWLF model was first verified against historical data. Second, the GWLF was run for a reference period (the late $20^{\text {th }}$ century period), for the early and late $21^{\text {st }}$ century to assess the potential impacts of these changes on streamflow. Finally, the relative change between two projection periods in streamflow was calculated. All GCMs for each climate scenario were used to analyse streamflow impacts. Table 3 shows the number of GCM and the $\mathrm{CO}_{2}$ concentration for each climate scenario.

Three statistical indices were used to evaluate the GWLF model performance levels in a validation period, namely the Nash-Sutcliffe efficiency (NSE) coefficient, the coefficient of correlation (R), and the root-mean-square error (RMSE). Each performance index is described as follows:

(1) NSE Coefficient

$\mathrm{NSE}=1-\frac{\sum_{i=1}^{n}\left(O_{i}-S_{i}\right)^{2}}{\sum_{i=1}^{n}\left(O_{i}-\bar{O}\right)^{2}}$ 
where $O_{i}$ is the observed streamflow for month $i, S_{i}$ is the simulated stream flow for month $i, \bar{O}$ is the mean of observed streamflow, and $n$ is the number of data. The NSE value can range from $-\infty$ to 1 . The closer the NSE is to 1 , the more accurate the model is. NSE is sensitive to extreme values and might yield suboptimal results when the data set contains large outliers (Nash and Sutcliffe 1970).

(2) Coefficient of Correlation

$$
\mathrm{R}=\frac{\sum_{i=1}^{n}\left(O_{i}-\bar{O}\right)\left(S_{i}-\bar{S}\right)}{\sqrt{\sum_{i=1}^{n}\left(O_{i}-\bar{O}\right)^{2} \sum_{i=1}^{n}\left(S_{i}-\bar{S}\right)^{2}}}
$$

where $\bar{S}$ is the mean of simulated streamflow, and $R$ ranges between -1 and 1 . An $R$ value close to 1 indicates that the variables are positively linearly related. An $R$ value of zero means there is no correlation between the observed and simulated streamflow.

(3) RMSE

$\operatorname{RMSE}=\sqrt{\frac{\sum_{i=1}^{n}\left(O_{i}-S_{i}\right)^{2}}{n}}$

The RMSE represents the sample standard deviation of the differences between the observed streamflow and simulated streamflow.

\subsection{Cumulative Probability of Change Ratio of Streamflow}

The change ratio of streamflow is the difference in monthly stream flow between the late $20^{\text {th }}$ century period and the $21^{\text {st }}$ century period divided by the streamflow in the late $20^{\text {th }}$ century period. The average change ratio of streamflow in a spell (which is called RSt) was calculated in different GCMs during the two projected periods and was used to explain climate change impacts. In this notation, $\mathrm{t}=1$ means "in a wet spell"; other values of $t$ mean "in a dry spell".

There are $126 \mathrm{RSt}$ results in different spells from all GCMs and RCPs. The empirical cumulative distribution function $(E C D F)$ is used to show the cumulative probability of RSt for each RCP. The following plotting position formula (Weibull 1939) is used for estimating empirical cumulative probability:

$p=\frac{i}{n+1}$

where $p$ is the calculated plotting position; $i$ is the rank of the data; and $n$ is the number of data.

The RSt values from different GCMs are ranked in descending order to calculate the percentiles of the data that are either less than or greater than a particular data value. For instance, the cumulative probability at $\mathrm{RSt}=0$ is greater than 0.5 , which indicates that the results of most predictions show a decline. Conversely, the cumulative probability at $\mathrm{RSt}=0$ is less than 0.5 which indicates that the results of most predictions show an increase.

\section{RESULTS AND DISCUSSION}

The GWLF was first verified and then applied to evaluate the streamflow impacts under different GCMs and climate change scenarios. The simulation results are discussed in sections 4.2 to 4.5 .

\subsection{GWLF Verification}

The evapotranspiration cover coefficients were required for GWLF verification and were determined according to the land use and soil texture. The results showed that the GWLF model could predict the monthly streamflow with satisfactory accuracy (Fig. 4 and Table 4). The streamflow and weather data for 1980 - 1999 for the Dahan River and 1982 - 2008 for the Laonong River were used. According to the three statistical performance indices, the Dahan River exhibited better performance values than those for the Laonong River. The Dahan and Laonong River correlation coefficients were 0.89 and 0.83 , respectively. The GWLF model could capture the months with high and low streamflow (Fig. 4). The simulations of the GWLF could determine the trends and the directions of changes in streamflow caused by climate change, even though the calibration was not satisfactory (Niraula et al. 2015). The GWLF was applied to simulate relative changes of streamflow under climate change impacts in this study, even though the NSE value for the Laonong River was not satisfactory but the deviation was still acceptable for climate change impact assessment.

\subsection{Impacts of Climate Change on Streamflow in Wet and Dry Spells}

The impacts of climate change on streamflow in the two catchments were evaluated using all GCMs for all RCPs. Figure 5 shows the ECDF for the RSt during wet and dry spells (the wet spell is from May to October, and the dry spell is from November to April of the following year) under climate change in the early $21^{\text {st }}$ century. Figure 5 shows that the variation between different RCPs was insignificant. Figures $5 \mathrm{a}$ and $\mathrm{b}$ show the RSt falling between $-40 \%$ and $40 \%$ during wet and dry spells in the Dahan River. The ECDF shows that more than $60 \%$ of GCMs projections for the RCPs exhibit an increase of $0-40 \%$ for streamflow in wet spells and a decrease of $-40 \sim 0 \%$ in dry spells. Therefore, the discharge of the Dahan River increases during the 
Table 3. The number of GCMs and $\mathrm{CO}_{2}$ Concentration of the RCP Scenarios.

\begin{tabular}{ccccc}
\hline Climate scenario & RCP2.6 & RCP4.5 & RCP6.0 & RCP8.5 \\
\hline Number of GCMs & 26 & 38 & 21 & 41 \\
Atmospheric $\mathrm{CO}_{2}$ equivalent (parts per million) & 490 & 650 & 850 & $>1370$ \\
\hline
\end{tabular}
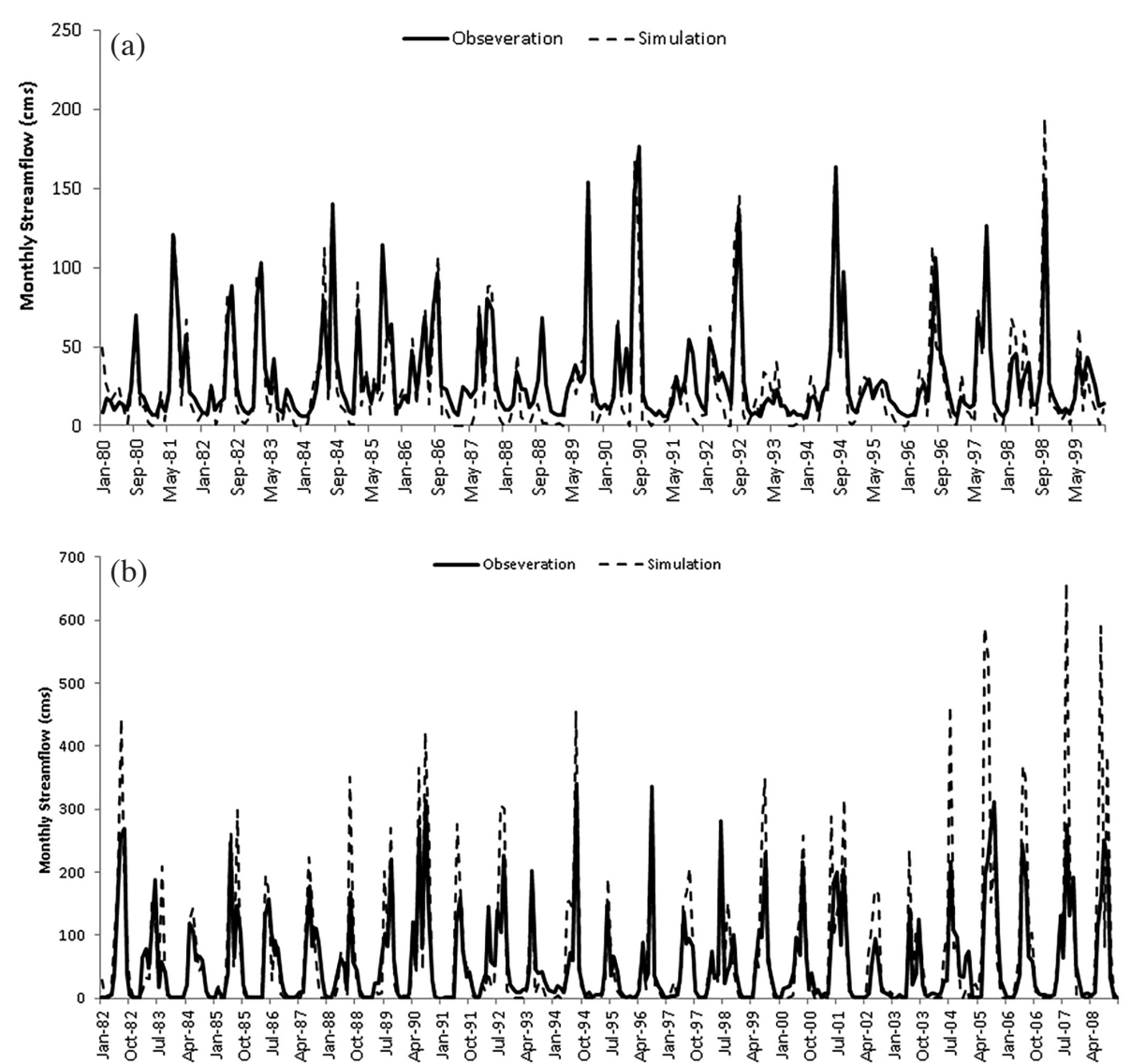

Fig. 4. The simulation and observation streamflow in the verification period (a) Dahan River (1980 - 1999) (b) Laonong River (1982 - 2008).

Table 4. GWLF Performance Index during Verification Period for Streamflow.

\begin{tabular}{ccc}
\hline Index & Dahan River & Laonong River \\
\hline $\mathrm{R}$ & 0.89 & 0.83 \\
$\mathrm{NSE}$ & 0.84 & 0.14 \\
$\mathrm{RMSE}$ & 7.88 & 15.1 \\
\hline
\end{tabular}



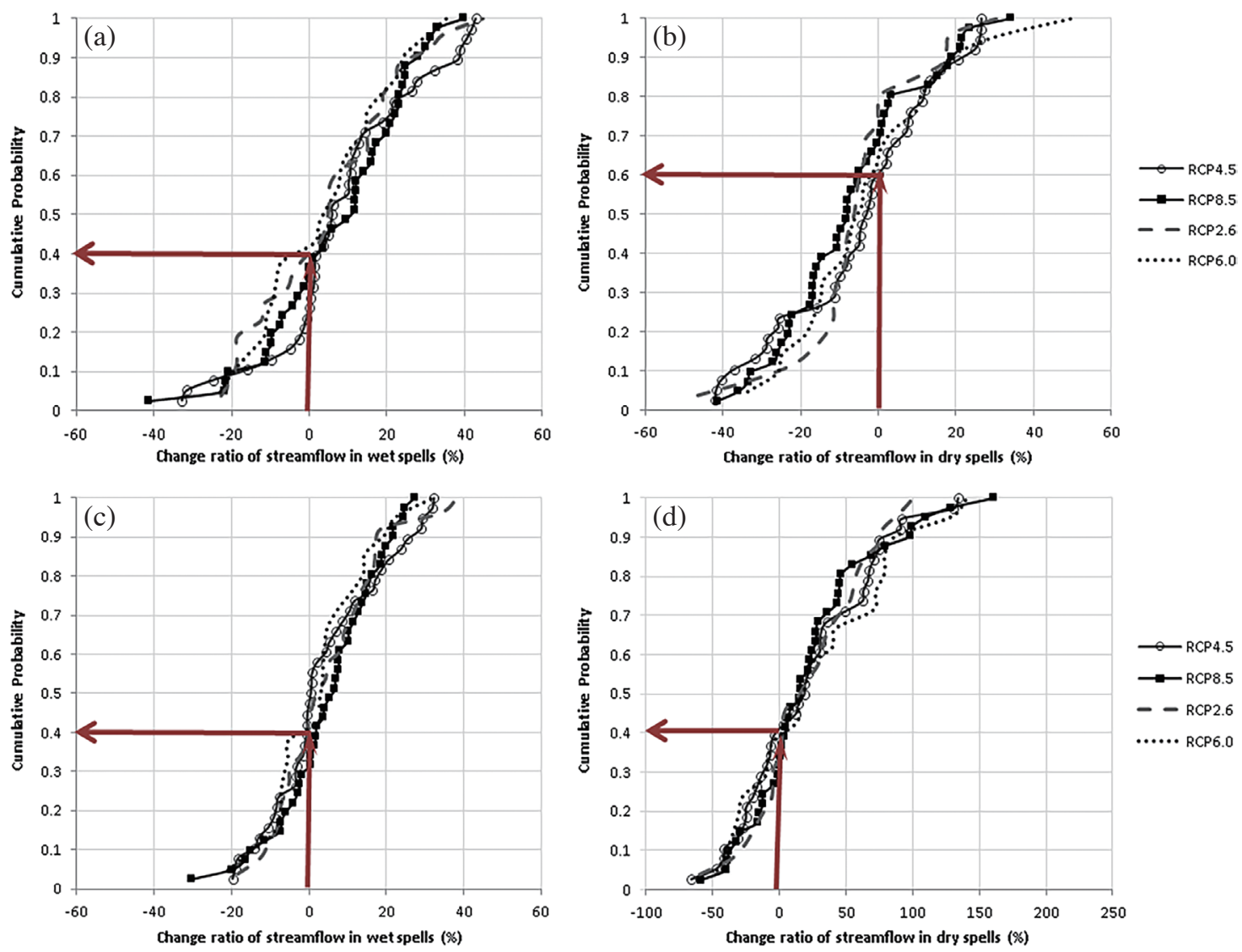

Fig. 5. The ECDF of RSt in wet and dry spells during the early $21^{\text {st }}$ century; (a) Wet spell of Dahan River, (b) Dry spell of Dahan River, (c) Wet spell of Laonong River, and (d) Dry spell of Laonong River.

wet spells and decreases during the dry spells because of RCP impacts. However, the variation in streamflow for the Laonong River is different. Figures $5 \mathrm{c}$ and $\mathrm{d}$ show that the streamflow increases during wet spells and dry spells in projections from more than $60 \%$ of GCMs. The RSt is roughly $-20 \sim 30 \%$ in wet spells and roughly $-60 \sim 150 \%$ in dry spells for the Laonong River. Therefore, the RSt values in dry spells for the Laonong River are different from those of the Dahan River in the early $21^{\text {st }}$ century.

The RSt values in RCP8.5 scenarios were selected for comparisons of different projection periods (early and late $21^{\text {st }}$ century). Figures $6 a$ and $b$ show the ECDFs of streamflow change ratios during wet and dry spells during the two projection periods in the two catchments. Figure 6a shows that, in RCP8.5 scenarios for the Dahan River, the RSt value at $80 \%$ cumulative probability in wet spells becomes higher in the late $21^{\text {st }}$ century than that in the early $21^{\text {st }}$ century. In addition, the RSt value at $20 \%$ exceedance probability in dry spells becomes lower in the late $21^{\text {st }}$ century than that in the early $21^{\text {st }}$ century. Because the ECDF of RSt in wet spells in the late $21^{\text {st }}$ century (RCP8.5-F-Wet) shifts to the right side and the ECDF in dry spells (RCP8.5-F-Dry) then shifts to the left side. Figure $6 \mathrm{~b}$ shows that the ECDF of RSt decreases in dry spells (RCP8.5-F-Dry) in 70\% of
GCM projections for the Laonong River during the late $21^{\text {st }}$ century. The streamflow change trend in wet and dry spells in the late $21^{\text {st }}$ century is the same that as found in previous researches (Yu et al. 2002; Li et al. 2009) that applied assumed precipitation scenarios and TAR data to assess streamflow impacts in Taiwan. The streamflow impacts are more serious in AR5.

\subsection{Impacts of Monthly Streamflow}

Box plots of the monthly streamflow change ratios are shown in Fig. 7. The MME comprises a large number of climate model simulations created using many different GCMs. Since the MME improves the robustness of climate change projections (Diallo et al. 2012; Knutti and Sedláček 2013), its use in climate change impact assessment is suggested. The MME projection was able to present the trend of climate change impacts and was analysed in this section. The box plots show the maximum value, minimum value, lower quartile $\left(25^{\text {th }}\right.$ percentile $)$, upper quartile $\left(75^{\text {th }}\right.$ percentile), and median $\left(50^{\text {th }}\right.$ percentile); the dots outside the boxes are considered as outliers. The box size (i.e., interquartile range) could be an index used to represent the variance in the monthly streamflow change ratio. Figure 7 a shows 

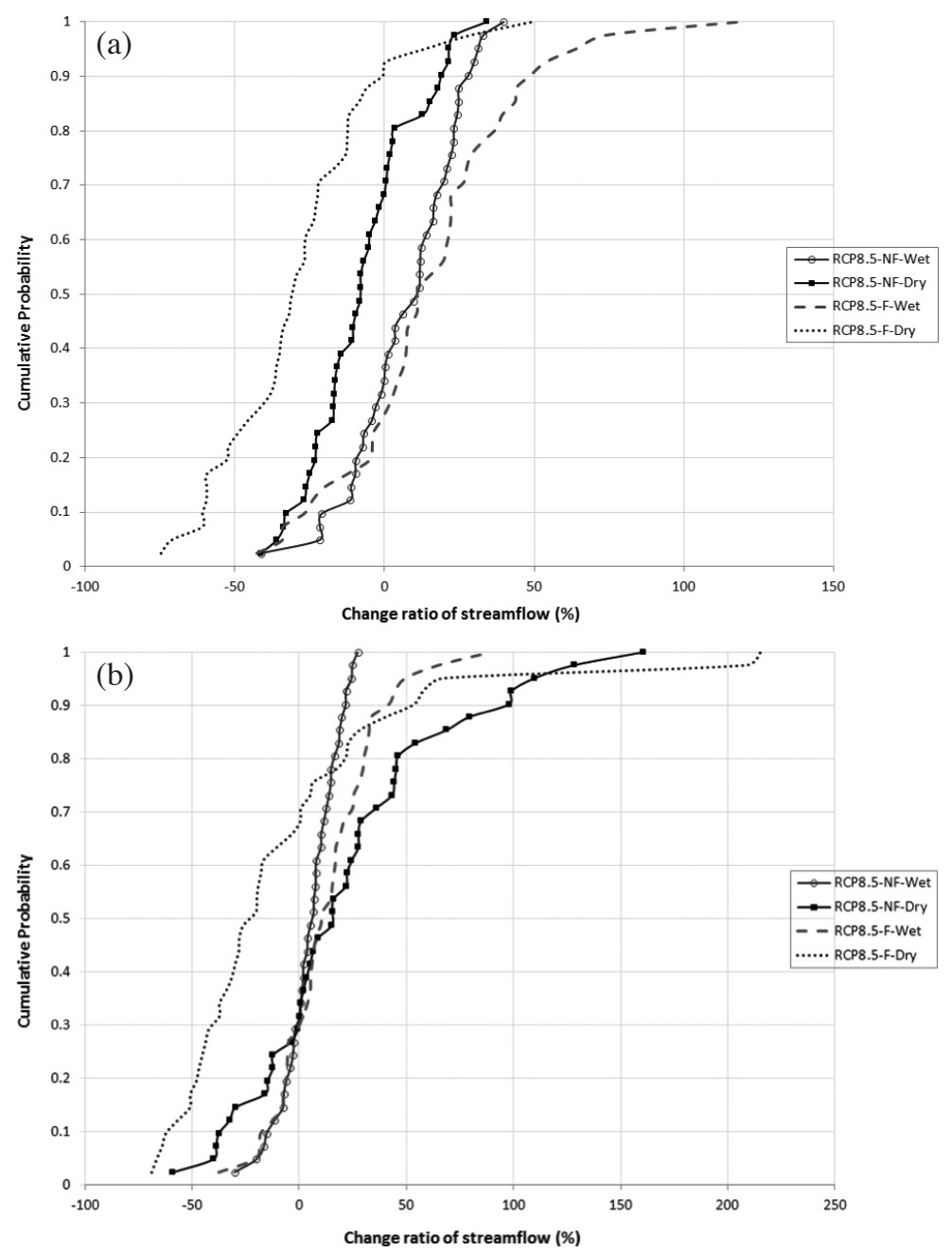

Fig. 6. The ECDF of RSt in different spells during two projection periods in RCP8.5 scenarios; (a) Dahan River, (b) Laonong River. Note: 'Wet' means the wet spells, 'Dry' means the dry spell, 'NF' means during the early $21^{\text {st }}$ century, and ' $F$ ' means during the late $21^{\text {st }}$ century.
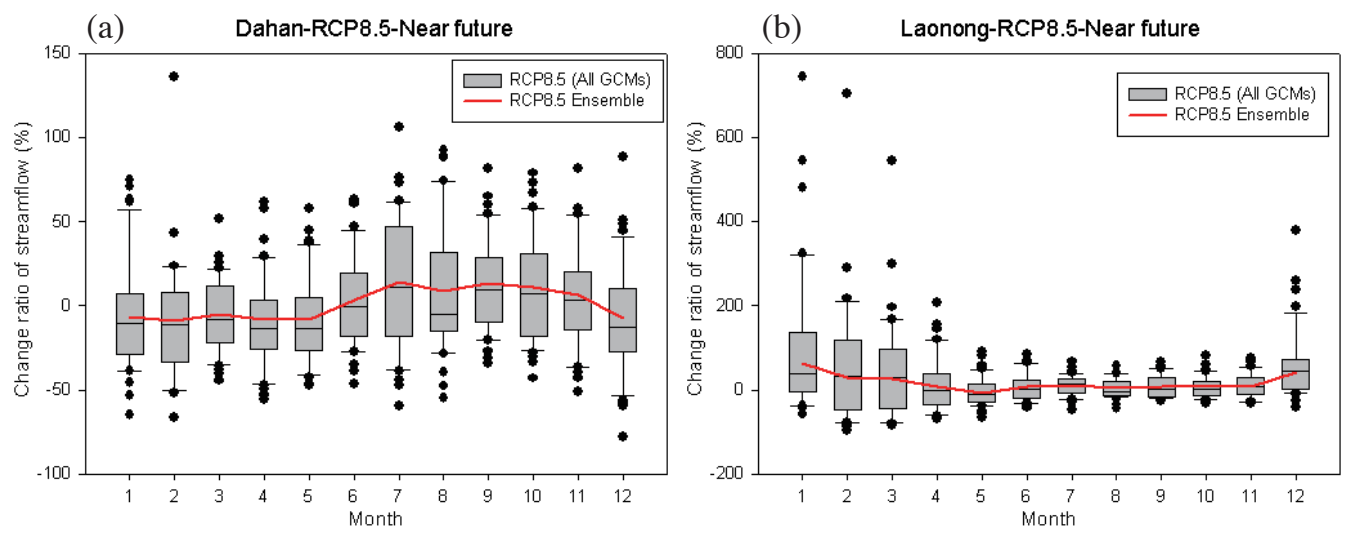

Fig. 7. The box plot of monthly streamflow change ratio under RCP8.5 scenarios in the early $21^{\text {st }}$ century in two catchments; (a) Dahan River, (b) Laonong River. 
that the variability in monthly streamflow change ratios for July and August (during a wet spell) are greater than usual for the Dahan River under RCP8.5 scenarios, whereas in Fig. 7b, greater than usual variability is shown in February and March (during a dry spell) for the Laonong River. The change ratio of streamflow from the MME is smaller than that of all GCMs.

Figure 8 shows the monthly streamflow change ratios from the MME projection in the two catchments. The variation between the two catchments is closer during the period from June to November. The streamflow increases in wet spells. The variation is significant during the dry spell from December to April of the next year. The Dahan River streamflow decreases while the Laonong River streamflow increases. This study recommends using the MME predictions for climate change assessment because the MME projections could decrease the uncertainty. The MME projections of streamflow impacts could be applied to plan adaptations.

\subsection{The Number of GCMs in Various Streamflow Change Ratio}

The RSt results for all GCMs in all RCPs (126 results) for the late $21^{\text {st }}$ century were divided into six intervals. The numbers of GCM projections for specific RSt values in wet and dry spells were counted in all intervals. Table 5 shows that the 25 GCMs exhibited a $0-30 \%$ RSt in the wet spell and a $-30 \sim-1 \%$ RSt in the dry spell. Most of these results should be considered and anticipated in plans for the future. Taiwan's decision makers can formulate adaptation strategies according to the predictions addressing 30\% increases in Dahan River streamflow during wet spells and 30\% decreases in Dahan River streamflow during dry spells. These plans would be used to solve streamflow impacts at the late $21^{\text {st }}$ century. The Laonong River situation is different, as shown in Table 6. Its streamflow change ratio showed that more GCM models fell in the $0-30 \%$ interval during wet spells and in the $-30 \sim-60 \%$ interval during dry spells. The
Laonong River shows a greater change ratio in the dry spells than the Dahan River shows. Therefore, the adaptation measures to the Laonong River for the dry spells should have higher priority.

\subsection{Comparisons of all GCMs and Selected Models}

Most climatic researchers suggest that climate change impact assessments should involve analysing all GCMs and scenarios to reduce the climate change projection uncertainty. However, the process of impact assessment is so complicated that most hydrologic researchers cannot evaluate all projections in all relevant sectors. Therefore, selecting a few representative GCMs to assess impacts is necessary. Figure 9 presents a comparison between using a few GCMs and all GCMs to assess streamflow impacts. In Fig. 9 , the 20 GCMs (see Table 2) with four scenarios were selected for a comparison with all GCMs. The Laonong River was used as a case study to present the variance in RSt. The results show that the projections of all GCMs and the 20 GCMs present no significant difference under the four scenarios. Even in dry and wet seasons, the results show similar changes in streamflow. Because there is no significant difference, the user can apply the selected $20 \mathrm{GCMs}$ with four scenarios to predict the impact of future changes to Taiwan's climate.

\section{SUMMARY AND CONCLUSIONS}

The impacts of climate change on streamflow for two catchments in Taiwan were investigated. Statistical downscaling data based on the AR5 GCMs projections for all scenarios were considered. According to the projected streamflow change rates for the early $21^{\text {st }}$ century, approximately more than $60 \%$ of the GCMs projections indicated increased $(+40 \%)$ streamflow during wet spells and decreased (-40\%) streamflow during dry spells for the Dahan River in Northern Taiwan. The GCMs tended to predict an increased streamflow change rate for the Laonong River

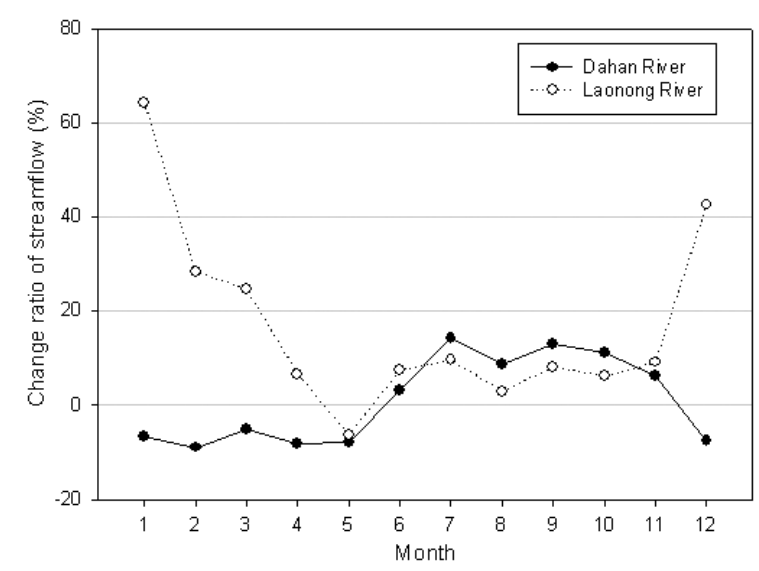

Fig. 8. The monthly streamflow change ratio by MME under RCP8.5 scenarios in the early $21^{\text {st }}$ century. 
Table 5. The RSt in Different Intervals for Dahan River in the late $21^{\text {st }}$ Century.

\begin{tabular}{|c|c|c|c|c|c|c|c|}
\hline \multirow{2}{*}{\multicolumn{2}{|c|}{ Change ratio interval }} & \multicolumn{6}{|c|}{ Change ratio of streamflow in dry spells $(\%)$} \\
\hline & & $>60$ & $31 \sim 60$ & $\mathbf{0} \sim 30$ & $-30 \sim-1$ & $-60 \sim-31$ & $<-60$ \\
\hline \multirow{6}{*}{$\begin{array}{c}\text { Change ratio of streamflow in } \\
\text { wet spells }(\%)\end{array}$} & $>60$ & 0 & 2 & 1 & 1 & 2 & 0 \\
\hline & $31 \sim 60$ & 0 & 1 & 4 & 4 & 5 & 0 \\
\hline & $0 \sim 30$ & 0 & 7 & 14 & 25 & 18 & 4 \\
\hline & $-30 \sim-1$ & 0 & 0 & 9 & 22 & 2 & 1 \\
\hline & $-60 \sim-31$ & 0 & 0 & 1 & 1 & 2 & 0 \\
\hline & $<-60$ & 0 & 0 & 0 & 0 & 0 & 0 \\
\hline
\end{tabular}

Table 6. The RSt in Different Intervals for Laonong River in the late $21^{\text {st }}$ Century.

\begin{tabular}{c|c|ccc|ccc}
\hline \multirow{2}{*}{ Change ratio interval } & \multicolumn{5}{c}{ Change ratio of streamflow in dry spells $(\%)$} \\
\cline { 3 - 8 } & $>60$ & 1 & 0 & 1 & 1 & 0 & 0 \\
\hline \multirow{4}{*}{$\begin{array}{c}\text { Change ratio of streamflow in } \\
\text { wet spells (\%) }\end{array}$} & $31 \sim 60$ & 6 & 0 & 3 & 4 & 2 & 1 \\
& $0 \sim 30$ & 16 & 9 & 10 & 16 & $\mathbf{1 9}$ & 4 \\
& $-30 \sim-1$ & 3 & 6 & 7 & 9 & 6 & 1 \\
& $-60 \sim-31$ & 0 & 0 & 0 & 0 & 0 & 1 \\
& $<-60$ & 0 & 0 & 0 & 0 & 0 & 0 \\
\hline
\end{tabular}
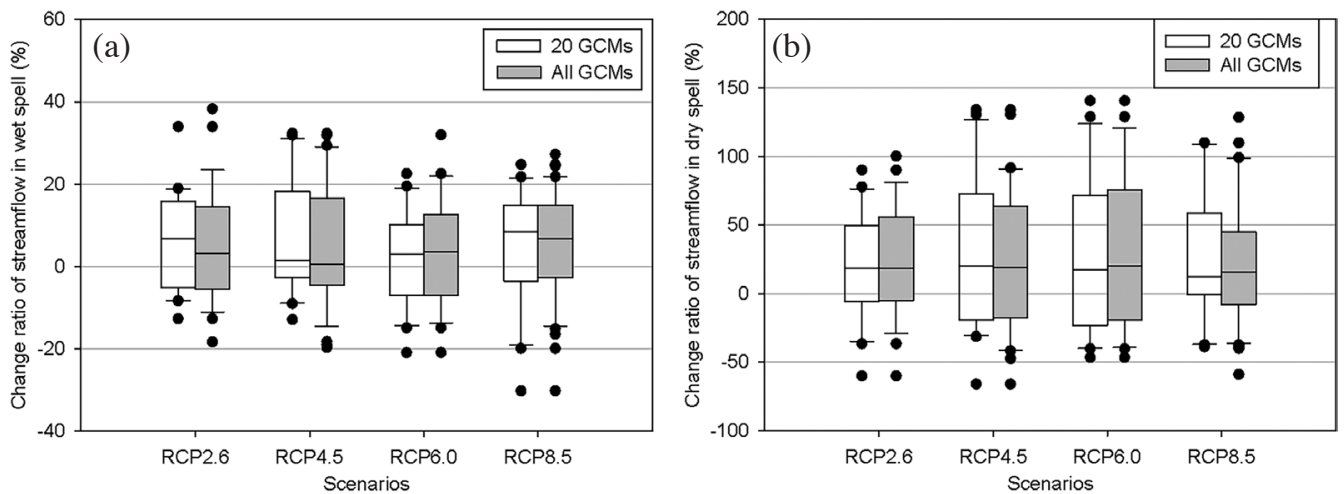

Fig. 9. The RSt for 20 GCMs and all GCMs under different RCPs in different spell; (a) Wet spell, (b) Dry spell.

in Southern Taiwan for both wet and dry spells during the early $21^{\text {st }}$ century period. Compared with the Dahan River, a larger change rate variance in streamflow was found during the dry spell in the Laonong River. By contrast, an increased (decreased) streamflow change rate during wet (dry) spells was found in both catchments for the late $21^{\text {st }}$ century period. These results imply that more flexible strategies for reservoir operations and water deployment will be necessary during dry spells in the future.

According to the IPCC (2014) prediction that various climate change signals will be more discernible at the late $21^{\text {st }}$ century, Taiwan's decision makers require specific and clear projections of streamflow for adapting Taiwan's water resource strategies to the impacts of climate change. The MME could decrease the projection uncertainty. Therefore, it is suggested that the decision makers plan adaptations based on the MME projections of streamflow.

The comparisons of all GCMs and the 20 selected GCMs for different RCP scenarios revealed no significant differences. The selected scenarios and GCMs did not reduce the variance for the streamflow change ratio under climate change.

According to the streamflow statistical variability interval calculated for the late $21^{\text {st }}$ century, most GCMs show a streamflow increase of $30 \%$ during wet spells and a 30\% decrease during dry spells for the Dahan River. The 
Laonong River showed a 30\% increase during the wet spells and a $60 \%$ decrease during the dry spells. Water source development and conservation measures must be established for dry spells in Southern Taiwan.

Acknowledgements The authors show their deep appreciation to TCCIP project (MOST 102-2621-M-492-001 and MOST 103-2621-M-865-001) to provide statistical downscaling data.

\section{REFERENCES}

Andréasson, J., S. Bergström, B. Carlsson, L. P. Graham, and G. Lindström, 2004: Hydrological change - Climate change impact simulations for Sweden. AM$B I O, 33$, 228-234, doi: 10.1579/0044-7447-33.4.228. [Link]

Bae, D. H., I. W. Jung, and D. P. Lettenmaier, 2011: Hydrologic uncertainties in climate change from IPCC AR4 GCM simulations of the Chungju Basin, Korea. J. Hydrol., 401, 90-105, doi: 10.1016/j.jhydrol.2011.02.012. [Link]

Barnett, T. P., J. C. Adam, and D. P. Lettenmaier, 2005: Potential impacts of a warming climate on water availability in snow-dominated regions. Nature, 438, 303309, doi: 10.1038/nature04141. [Link]

Benestad, R. E., 2002: Empirically downscaled multimodel ensemble temperature and precipitation scenarios for Norway. J. Climate, 15, 3008-3027, doi: 10.1175/1520 -0442(2002)015<3008:EDMETA>2.0.CO;2. [Link]

Carter, T. R., 2001: Uncertainties in assessing the impacts of regional climate change. In: India, M. B. and D. L. Bonillo (Eds.), Detecting and Modelling Regional Climate Change, Springer Berlin Heidelberg, 441-469, doi: 10.1007/978-3-662-04313-4_38. [Link]

Chang, H., 2003: Basin hydrologic response to changes in climate and land use: the Conestoga River Basin, Pennsylvania. Phys. Geogr., 24, 222-247.

Charlton, R., R. Fealy, S. Moore, J. Sweeney, and C. Murphy, 2006: Assessing the impact of climate change on water supply and flood hazard in Ireland using statistical downscaling and hydrological modelling techniques. Clim. Change, 74, 475-491, doi: 10.1007/ s10584-006-0472-x. [Link]

Chen, C. T., J. L. Chu, H. H. Hsu, M. M. Lu, C. H. Sui, C. Chou, S. P. Weng, J. M. Chen, C. Y. Lin, C. T. Cheng, Y. C. Wu, Y. M. Cho, J. G. Chen, Y. J. Chang, S. Y. Lin, S. L. Lin, Y. S. Tung, and C. D. Yang, 2014: Projection of climate change over Taiwan using statistical downscaling scheme. Atmos. Sci., 42, 207-251. (in Chinese)

Chiang, J. L., H. C. Yang, Y. R. Chen, and M. H. Lee, 2013: Potential impact of climate change on hydropower generation in Southern Taiwan. Energy Procedia, 40,
34-37, doi: 10.1016/j.egypro.2013.08.005. [Link]

Chiew, F. H. S., P. H. Whetton, T. A. McMahon, and A. B. Pittock, 1995: Simulation of the impacts of climate change on runoff and soil moisture in Australian catchments. J. Hydrol., 167, 121-147, doi: 10.1016/00221694(94)02649-V. [Link]

Chu, J. L., H. Kang, C. Y. Tam, C. K. Park, and C. T. Chen, 2008: Seasonal forecast for local precipitation over northern Taiwan using statistical downscaling. J. Geophys. Res., 113, D12118, doi: 10.1029/2007JD009424. [Link]

Diallo, I., M. B. Sylla, F. Giorgi, A. T. Gaye, and M. Camara, 2012: Multimodel GCM-RCM ensemble-based projections of temperature and precipitation over West Africa for the early 21st Century. Int. J. Geophys., 2012, doi: 10.1155/2012/972896. [Link]

Evans, B. M., D. W. Lehning, K. J. Corradini, G. W. Petersen, E. Nizeyimana, J. M. Hamlett, P. D. Robillard, and R. L. Day, 2002: A comprehensive GIS-based modeling approach for predicting nutrient loads in watersheds. J. Spatial Hydrol., 2, 1-18.

Fowler, H. J., S. Blenkinsop, and C. Tebaldi, 2007: Linking climate change modelling to impacts studies: Recent advances in downscaling techniques for hydrological modelling. Int. J. Climatol., 27, 1547-1578, doi: 10.1002/joc.1556. [Link]

Gosling, S. N. and N. W. Arnell, 2011: Simulating current global river runoff with a global hydrological model: Model revisions, validation, and sensitivity analysis. Hydrol. Process., 25, 1129-1145, doi: 10.1002/ hyp.7727. [Link]

Haith, D. A. and L. L. Shoenaker, 1987: Generalized watershed loading functions for stream flow nutrients. $J$. Am. Water Resour. Assoc., 23, 471-478, doi: 10.1111/ j.1752-1688.1987.tb00825.x. [Link]

Haith, D. A., R. Mandel, and R. S. Wu, 1992: GWLF: Generalized Watershed Loading Functions, User's Manual, Version 2.0, Department of Agricultural \& Biological Engineering, Cornell University, Ithaca, NY.

Hay, L. E. and M. P. Clark, 2003: Use of statistically and dynamically downscaled atmospheric model output for hydrologic simulations in three mountainous basins in the western United States. J. Hydrol., 282, 56-75, doi: 10.1016/S0022-1694(03)00252-X. [Link]

Hong, S. J., B. S. Kim, and S. R. Ha, 2014: Climate change impact assessment on Han River long term runoff in South Korea based on RCP climate change scenario. Terr. Atmos. Ocean. Sci., 25, 689-701, doi: 10.3319/ TAO.2014.05.08.01(Hy). [Link]

Hughes, J. P. and P. Guttorp, 1994: A class of stochastic models for relating synoptic atmospheric patterns to regional hydrologic phenomena. Water Resour. Res., 30, 1535-1546, doi: 10.1029/93WR02983. [Link]

IPCC, 2014: Summary for policymakers. In: Field, C. B., 
V. R. Barros, D. J. Dokken, K. J. Mach, M. D. Mastrandrea, T. E. Bilir, M. Chatterjee, K. L. Ebi, Y. O. Estrada, R. C. Genova, B. Girma, E. S. Kissel, A. N. Levy, S. MacCracken, P. R. Mastrandrea, and L. L. White (Eds.), Climate Change 2014: Impacts, Adaptation, and Vulnerability, Part A: Global and Sectoral Aspects, Contribution of Working Group II to the Fifth Assessment Report of the Intergovernmental Panel on Climate Change, Cambridge University Press, Cambridge, United Kingdom and New York, NY, USA, $1-32$.

Knutti, R. and J. Sedláček, 2013: Robustness and uncertainties in the new CMIP5 climate model projections. Nat. Clim. Change, 3, 369-373, doi: 10.1038/nclimate1716. [Link]

Li, M. H., W. Tien, and C. P. Tung, 2009: Assessing the impact of climate change on the land hydrology in Taiwan. Paddy Water Environ., 7, 283-292, doi: 10.1007/ s10333-009-0175-9. [Link]

Lin, S. H., C. M. Liu, W. C. Huang, S. S. Lin, T. H. Yen, H. R. Wang, J. T. Kuo, and Y. C. Lee, 2010: Developing a yearly warning index to assess the climatic impact on the water resources of Taiwan, a complexterrain island. J. Hydrol., 390, 13-22, doi: 10.1016/j. jhydrol.2010.06.024. [Link]

Maraun, D., F. Wetterhall, A. M. Ireson, R. E. Chandler, E. J. Kendon, M. Widmann, S. Brienen, H. W. Rust, T. Sauter, M. Themeß1, V. K. C. Venema, K. P. Chun, C. M. Goodess, R. G. Jones, C. Onof, M. Vrac, and I. ThieleEich, 2010: Precipitation downscaling under climate change: Recent developments to bridge the gap between dynamical models and the end user. Rev. Geophys., 48, RG3003, doi: 10.1029/2009RG000314. [Link]

Maurer, E. P., 2007: Uncertainty in hydrologic impacts of climate change in the Sierra Nevada, California, under two emissions scenarios. Clim. Change, 82, 309-325, doi: 10.1007/s10584-006-9180-9. [Link]

Maurer, E. P. and H. G. Hidalgo, 2008: Utility of daily vs. monthly large-scale climate data: An intercomparison of two statistical downscaling methods. Hydrol. Earth Syst. Sci., 12, 551-563, doi: 10.5194/ hessd-4-3413-2007. [Link]

Maurer, E. P., A. W. Wood, J. C. Adam, D. P. Lettenmaier, and B. Nijssen, 2002: A long-term hydrologically based dataset of land surface fluxes and states for the conterminous United States. J. Climate, 15, 3237-3251, doi: 10.1175/1520-0442(2002)015<3237:ALTHBD>2 .0.CO;2. [Link]

Mavromatis, T. and J.W. Hansen, 2001: Interannual variability characteristics and simulated crop response of four stochastic weather generators. Agric. For. Meteorol., 109, 283-296, doi: 10.1016/S0168-1923(01)00272-6. [Link]

Mitchell, T. D. and P. D. Jones, 2005: An improved method of constructing a database of monthly climate observations and associated high-resolution grids. Int. J. Climatol., 25, 693-712, doi: 10.1002/joc.1181. [Link]

Nash, J. E. and J. V. Sutcliffe, 1970: River flow forecasting through conceptual models. Part I - A discussion of principles. J. Hydrol., 10, 282-290, doi: 10.1016/00221694(70)90255-6. [Link]

Nawaz, N. R. and A. J. Adeloye, 2006: Monte Carlo assessment of sampling uncertainty of climate change impacts on water resources yield in Yorkshire, England. Clim. Change, 78, 257-292, doi: 10.1007/s10584-0059043-9. [Link]

Niraula, R., L. Kalin, P. Srivastava, and C. J. Anderson, 2013: Identifying critical source areas of nonpoint source pollution with SWAT and GWLF. Ecol. Model., 268, 123-133, doi: 10.1016/j.ecolmodel.2013.08.007. [Link]

Niraula, R., T. Meixner, and L. M. Norman, 2015: Determining the importance of model calibration for forecasting absolute/relative changes in streamflow from LULC and climate changes. J. Hydrol., 522, 439-451, doi: 10.1016/j.jhydrol.2015.01.007. [Link]

Prudhomme, C. and H. Davies, 2009: Assessing uncertainties in climate change impact analyses on the river flow regimes in the UK. Part 1: Baseline climate. Clim. Change, 93, 177-195, doi: 10.1007/s10584-008-94643. [Link]

Richardson, C. W., 1981: Stochastic simulation of daily precipitation, temperature, and solar radiation. Water Resour. Res., 17, 182-190, doi: 10.1029/ WR017i001p00182. [Link]

Richardson, C. W. and D. A. Wright, 1984: WGEN: A Model for Generating Daily Weather Variables, U. S. Department of Agriculture, Agricultural Research Service, ARS-8, 83 pp.

Roe, G. H. and M. A. O’Neal, 2009: The response of glaciers to intrinsic climate variability: Observations and models of late-Holocene variations in the Pacific Northwest. J. Glaciol., 55, 839-854, doi: 10.3189/002214309790152438. [Link]

Sato, Y., T. Kojiri, Y. Michihiro, Y. Suzuki, and E. Nakakita, 2012: Estimates of climate change impact on river discharge in Japan based on a super-high-resolution climate model. Terr. Atmos. Ocean. Sci., 23, 527-540, doi: 10.3319/TAO.2012.05.03.02(WMH). [Link]

Schneiderman, E., M. Järvinen, E. Jennings, L. May, K. Moore, P. S. Naden, and D. Pierson, 2010: Modeling the effects of climate change on catchment hydrology with the GWLF model. In: George, D. G. (Ed.), The Impact of Climate Change on European Lakes, Aquatic Ecology Series 4, Springer Netherlands, 33-50, doi: 10.1007/978-90-481-2945-4_3. [Link]

Semenov, M. A. and R. J. Brooks, 1999: Spatial interpolation of the LARS-WG stochastic weather generator in 
Great Britain. Clim. Res., 11, 137-148, doi: 10.3354/ cr011137. [Link]

Thodsen, H., 2007: The influence of climate change on stream flow in Danish rivers. J. Hydrol., 333, 226-238, doi: 10.1016/j.jhydrol.2006.08.012. [Link]

Thompson, J. R., A. J. Green, D. G. Kingston, and S. N. Gosling, 2013: Assessment of uncertainty in river flow projections for the Mekong River using multiple GCMs and hydrological models. J. Hydrol., 486, 1-30, doi: 10.1016/j.jhydrol.2013.01.029. [Link]

Thompson, J. R., A. J. Green, and D. G. Kingston, 2014: Potential evapotranspiration-related uncertainty in climate change impacts on river flow: An assessment for the Mekong River basin. J. Hydrol., 510, 259-279, doi: 10.1016/j.jhydrol.2013.12.010. [Link]

Tsai, A. Y. and W.C. Huang, 2011: Impact of climate change on water resources in Taiwan. Terr. Atmos. Ocean. Sci., 22, 507-519, doi: 10.3319/TAO.2011.04.15.01(Hy). [Link]

Tung, C. P., 2001: Climate change impacts on water resources of the Tsengwen creek watershed in Taiwan. $J$. Am. Water Resour. Assoc., 37, 167-176, doi: 10.1111/ j.1752-1688.2001.tb05483.x. [Link]

Tung, C. P. and D. A. Haith, 1995: Global-warming effects on New York streamflows. J. Water Resour. Plan. Manage., 121, 216-225, doi: 10.1061/(ASCE)07339496(1995)121:2(216). [Link]

Tung, C. P., T. C. Lee, W. T. Liao, and Y. J Chen, 2012: Climate change impact assessment for sustainable water quality management. Terr. Atmos. Ocean. Sci., 23, 565576, doi: 10.3319/TAO.2012.05.22.01(WMH). [Link]

Von Storch, H. and F. W. Zwiers, 1984: Statistical Analysis in Climate Research, Cambridge University Press, doi: 10.1017/CBO9780511612336.004. [Link]

Weibull, W., 1939: A Statistical Theory of the Strength of Materials, Generalstabens Litografiska Anstalts Förlag, $45 \mathrm{pp}$.

Wilks, D. S. and R. L. Wilby, 1999: The weather generation game: A review of stochastic weather models. Prog. Phys. Geogr., 23, 329-357, doi: 10.1177/030913339902300302. [Link]

Wood, A. W., E. P. Maurer, A. Kumar, and D. P. Lettenmaier, 2002: Long-range experimental hydrologic forecasting for the eastern United States. J. Geophys. Res., 107, doi: 10.1029/2001JD000659. [Link]

Wood, A. W., L. R. Leung, V. Sridhar, and D. P. Lettenmaier, 2004: Hydrologic implications of dynamical and statistical approaches to downscaling climate model outputs. Clim. Change, 62, 189-216, doi: 10.1023/B:C LIM.0000013685.99609.9e. [Link]

Wu, W., C. A. S. Hall, and F. N. Scatena, 2007: Modelling the impact of recent land-cover changes on the stream flows in northeastern Puerto Rico. Hydrol. Process., 21, 2944-2956, doi: 10.1002/hyp.6515. [Link]

Yatagai, A., K. Kamiguchi, O. Arakawa, A. Hamada, N. Yasutomi, and A. Kitoh, 2012: APHRODITE: Constructing a long-term daily gridded precipitation dataset for Asia based on a dense network of rain gauges. Bull. Amer. Meteorol. Soc., 93, 1401-1415, doi: 10.1175/ BAMS-D-11-00122.1. [Link]

Yu, P. S., T. C. Yang, and C. K. Wu, 2002: Impact of climate change on water resources in southern Taiwan. J. Hydrol., 260, 161-175, doi: 10.1016/S00221694(01)00614-X. [Link] 